\title{
2ウェイ低水路を有する河川における 河床変動計算に関する研究 STUDY ON SIMULATION OF RIVERBED CHANGE FOR TWO-WAY CHANNEL RIVER
}

\author{
横山洋 1 渡邊康玄 ${ }^{2} \cdot$ 鈴木優一 $^{3}$ \\ Hiroshi YOKOYAMA, Yasuharu WATANABE and Yuichi SUZUKI \\ 1正会員 工修 北海道開発土木研究所 河川研究室（T062-8602 札幌市豊平区平岸1条3-1-34） \\ 2正会員 工博 北海道開発土木研究所 河川研究室 (同上) \\ 3正会員北海道開発土木研究所 河川研究室（同上）
}

\begin{abstract}
A project for river-restoration on the Shibetsu River was launched in 2000. For meander restoration, test flow of water started in March 2002 in a bifurcated channel formed by connecting the pre-improved channel (oxbow) with the present straight channel. In the eighteen months that have elapsed, the riverbanks and riverbed in the test section have greatly changed.

To analyze hydraulic phenomena under various conditions, this study aimed to develop a numerical calculation method that enables estimation of flow and riverbed evolution. We made calculations that reproduce riverbed evolution for the test section. The reproducibility was verified by comparing calculation results and measurements. We clarified the applicability and applicable range of the calculation method.
\end{abstract}

Key Words: Two-way main channel, Restoration of meandering river, 2-D shallow water equations, Numerical simulation

\section{1. 序論}

わが国では明治以降，多くの沖積河川において治水安 全度の確保のための水位低下や農地開発のための地下水 位低下を目的に, 河川改修や蛇行河道のショートカット が急速に進められ，従来は蛇行していた河川が直線化さ れることとなった。しかしながら近年では河川環境を取 り巻く情勢が変化してきており, 河川環境保全への要望 が大きくなっている．こうした中，1997年の河川法改正 が契機となり, 自然生態系の復元等河川環境に配慮した 川づくりが行われるようになってきた。

北海道東部を流れる標津川では，2000年から「自然復 元型川づくり」の試みが全国初の事例として進められて いる. 自然復元を行うに当たり，先例がないため河川工 学的にも生態工学的にもどのような現象が生じるかが不 明確であった。このため, 試験的に一部旧河道(三日月 湖)を利用し現河道(直線河道)と接続させた2ウエイ河道 での試験施工が2002年3月から開始されており，1年6ケ 月が経過した。この間, 試験区間では河岸や河床が大き く変動している。この様な事業を実施するに当たり，洪
水時を含めた流れや河床変動を予測しておくことは, 河 道計画策定および河道維持管理上非常に重要である.

蛇行河川の流れ・河床変動に関する研究は現在までに 数多くなされている. 例えば清水 ${ }^{1} は$ は蛇行河川の河床変 動について2次元浅水流方程式による数值計算モデルを 構築し，害河川への適用在行っている．また複断面蛇行 水路に関して福岡らはその水理学的特性を実験 ${ }^{2}$ 及び数 值解析犯により明らかにしている.

一方蛇行復元後の標津川のような, 直線低水路と蛇行 低水路が複合・併存する複断面流れについての研究例は 少ない。例えば佐藤らは, 蛇行水路と直線水路を複合さ せた水理模型実験を行い, 河床変動と砂州の挙動につい て考察を行っている゙). しかし実験では設定条件及び害 施可能な回数に限りがあり, 数值計算モデルの開発は複 雑な河川形状、多様な条件下における水理現象解析に大 きく資するといえる。

本研究では直線と蛇行水路が複合した流れの数值計算 モデルを開発することを目的としている．本論では最初 に計算モデルの概要を示す。その後標津川改修工事区間 を対象にした河床変動再現計算を行い，計算結果と実現 
象と比較し，再現性について検証する．最後に高水敷の 冠水も含めた出水時の河床変動予測計算を行った。

\section{2. 計算モデルの概説}

合流，分流を含む流れは水平方向に加えて鉛直方向に も混合を生じ，また高水敷と低水路の境界でも流速差及 び急激な地形変化により複雑な流れとなる．厳密に流れ と河床変動を解くには鉛直方向の流れも考慮した3次元 計算が望ましい。しかし3次元計算に要する時間は膨大 なものとなり，河川への適用は現状では困難である。そ こで実河川においては平面2次元的な流れ及び河床変動 が把握できればある程度現象を予測可能と考え，以下に 示す2次元浅水流方程式を一般座標系に変換して用いた。 なお移流項には1次精度風上差分法を用いている。

$$
\begin{gathered}
\frac{\partial u}{\partial t}+u \frac{\partial u}{\partial x}+v \frac{\partial u}{\partial y}=-g \frac{\partial H}{\partial x}-\frac{g n^{2} u \sqrt{u^{2}+v^{2}}}{h^{4 / 3}} \\
+\frac{\partial}{\partial x}\left(2 v_{t} \frac{\partial u}{\partial x}\right)+\frac{\partial}{\partial y}\left\{v_{t}\left(\frac{\partial u}{\partial y}+\frac{\partial v}{\partial x}\right)\right\} \\
\frac{\partial v}{\partial t}+u \frac{\partial v}{\partial x}+v \frac{\partial v}{\partial y}=-g \frac{\partial H}{\partial y}-\frac{g n^{2} v \sqrt{u^{2}+v^{2}}}{h^{4 / 3}} \\
+\frac{\partial}{\partial x}\left\{v_{t}\left(\frac{\partial u}{\partial y}+\frac{\partial v}{\partial x}\right)\right\}+\frac{\partial}{\partial y}\left(2 v_{t} \frac{\partial v}{\partial y}\right) \\
\frac{\partial h}{\partial t}+\frac{\partial(u h)}{\partial x}+\frac{\partial(v h)}{\partial y}=0
\end{gathered}
$$

ここで $u, v: x, y$ 方向の流速成分, $g$ : 重力加速度, $h$ : 水深, $H$ : 水位, $n$ : 底面粗度係数. また $v_{t}$ : 渦動粘 性係数であり, カルマン定数 $\kappa(=0.4)$, 摩擦速度 $U_{*}$, 水 深hを用いて次の式で表す。

$$
v_{t}=\frac{\kappa}{6} U_{*} h
$$

続いて流砂量式を示す．流砂はここでは単一粒径で掃 流砂のみ考慮し，評価式には芦田・道上の式を用いるも のとする。

$$
q_{B}=17.0 \tau_{*}^{1.5}\left(1-\frac{\tau_{*_{c}}}{\tau_{*}}\right)\left(1-\sqrt{\frac{\tau_{*_{c}}}{\tau_{*}}}\right) \sqrt{s g d^{3}}
$$

ここで $\tau^{*}$ : 無次元掃流力, $\tau^{*}{ }_{c}$ : 無次元限界掃流力, $s$ : 砂の水中比重 $(=1.65), d:$ 砂の平均粒径である.

流線主流方向及び法線方向の底面近傍流速 $u_{b}{ }^{s}, u_{b}{ }^{n}$ は以下の式(6), (7)で表す。

$$
\begin{gathered}
u_{b}{ }^{n}=\left(u^{2}+v^{2}\right)^{1 / 2} \\
u_{b}{ }^{n}=-\frac{\left(u^{2}+v^{2}\right)^{1 / 2} N^{*} h}{r_{s}}
\end{gathered}
$$

ここに $N^{*}$ : Engelundの定数 (=7.0)である. また $r_{s}$ は

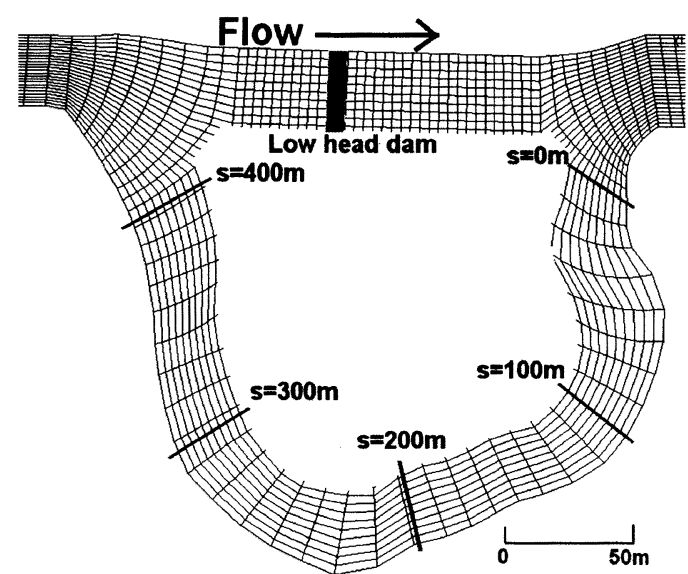

図-1＼cjkstart標津川蛇行復元試験区間の計算格子（左が上流）

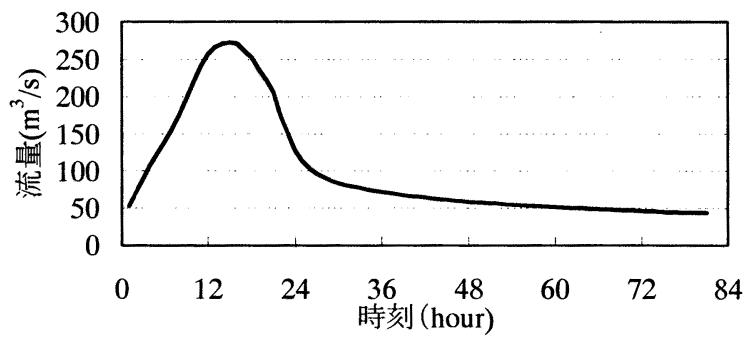

図-2＼cjkstart夏季出水のハイドログラフ

流線の曲率であり，以下の式を用いた5).

$$
\frac{1}{r_{s}}=\frac{1}{\left(\sqrt{u^{2}+v^{2}}\right)^{3}}\left[u\left(u \frac{\partial v}{\partial x}-v \frac{\partial u}{\partial x}\right)+v\left(u \frac{\partial v}{\partial y}+v \frac{\partial u}{\partial y}\right)\right]
$$

座標変換後の $\xi ， \eta$ 軸方向への流砂量の分配には局所 的な河床勾配を考慮した以下の式を用いた。

$q_{B}{ }^{\xi}=\xi_{r} q_{B} \frac{u_{b}^{\xi}}{\sqrt{u^{2}+v^{2}}} \sqrt{\frac{\tau_{* c}}{\mu_{s} \mu_{k} \tau_{*}}}\left(\xi_{r} \frac{\partial z_{b}}{\partial \xi}+\eta_{r} \frac{\partial z_{b}}{\partial \eta} \cos \theta\right)$

$q_{B}{ }^{n}=\eta_{r} q_{B} \frac{u_{b}{ }^{n}}{\sqrt{u^{2}+v^{2}}} \sqrt{\frac{\tau_{*}}{\mu_{s} \mu_{k} \tau}}\left(\xi_{r} \frac{\partial z_{b}}{\partial \xi} \cos \theta+\eta_{r} \frac{\partial z_{b}}{\partial \eta}\right)$

ここに $z_{b}$ : 河床高, $u_{b}{ }^{\xi}, u_{b}{ }^{\eta}$ : 底面近傍流速の $\xi$, $\eta$ 方向成分, $\xi_{r}=\Delta \xi / \Delta s, \eta_{r}=\Delta \eta / \Delta n, \mu_{s}, \mu_{k}$ : 河床 材料の静止摩擦係数及び動摩擦係数（本計算では $\left.\mu_{s} \mu_{k}=0.45\right) ， \theta$ : $\xi$ 軸と $\eta$ 軸のなす角である. 砂の空 隙率は 0.4 で計算を行った。

\section{3. 実河川2ウェイ水路への適用}

\section{(1)計算条件}

本計算モデルの適用性を検証するため，標津川蛇行復 元試験区間の河床変動予測計算に適用した。困-1は計算 格子である．灰色でマスクされた領域は，恒常的に流れ 及び河床変動計算を行わないダミ一領域である. 図-1中 のSは合流点からの距離である。

計算の諸条件を示す．上流端での流量設定は2002年4 月融雪洪水時の流量平均値 $47 \mathrm{~m}^{3} / \mathrm{s}$ を 1 週間与えた融雪出 
水時, 及び同年10月2〜4日のハイドログラフ（図-2）を 与えた夏季出水時の2ケースで行った. 下流端境界条件 は流下方向の水深変化がないものとした. 河床材料平均 粒径dは現地データに基づいて11mmとした。マニングの 粗度係数 $\mathrm{n}$ は現地で小規模河床形態が生じていないこと から, 平坦床の抵抗則として以下の式(11)で得られる值 を用いている。

$$
\mathrm{n}=\frac{\mathrm{d}^{1 / 6}}{6.9 \sqrt{\mathrm{g}}}
$$

2ウェイ部分における両低水路の初期河床形状は, 融 雪出水時の場合は2002年3月の測量結果, 夏季出水の場 合は同年9月の測量結果を用いる. なお2ウェイ部分上下 流に延びる直線河道の水路初期形状は矩形断面としてす りつけを行い, 縦断勾配は計画値である1/800を用いて いる. また堰上では洗堀は生じないことから, 堰に該当 するメッシュでは計算中に河床高が堰の標高よりも低く なる場合は河床変動を計算しないという簡易な方法で, その影響を計算に取り込んでいる。

\section{(2)融雪出水計算結果}

まず融雪出水による河床変動を娭証する。図-3(a)は融 雪出水前 (3月），(b)は出水完了後（7月）の現地河床高 である. 現地3月河床は計算初期河床形状としても用い た. 図-4は通水開始1週間後の河床形状計算値である.

合流地点直下流での初期河床において左岸側にあった 堆積が, 融雪出水後の現地7月河床では流失しており, 右岸側も出水前後を比べると洗堀の傾向にある. 計算値 でも同様の傾向が出ており, シミュレーションによる合 流点直下の現象再現は概ね良好といえる. 一方堰下流で は計算において明らかな河床の上昇を示しているのに対 し，現地では明確な変化は見られない。

蛇行水路をみると, 現地河床は流入口ならびに流入口 右岸から水路前半部にかけて上昇傾向にあり, 蛇行の頂 部付近では外岸側に洗堀がみられる. また合流部手前で は水路中心部から左岸寄りに洗堀が生じている. しかし 計算結果では蛇行部での河床変動は分流・合流点近傍以 外ではほとんど生じていない。

以上河床変動計算と現地河床の比較結果をまとめると, 直線河道部では部分的に現地傾向を再現しているものの, 分流, 合流点付近及び蛇行水路内の再現性は十分とはい えない.そこで四-5に示す無次元掃流力て ${ }^{*}$ の分布を見 ることとする。粒径 $11 \mathrm{~mm}$ の限界無次元掃流力 $\boldsymbol{~}^{*}{ }_{\mathrm{c}}$ は岩

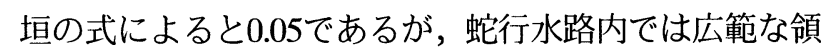
域で $\tau^{*}<\tau^{*}{ }_{\mathrm{c}}$ となっている. 現在のシミュレーションモ デルでは簡単のため土砂の粒径を平均值で評価している が, 実際の河床ではより細かい粒径も相当混在しており, これらが平均粒径規模の砂礫より小さい流速でも掃流さ れ, 単一粒径とは異なる河床変動を示すと考えられる.

なお蛇行部への流入流量は, 融雪出水期の実測で全流

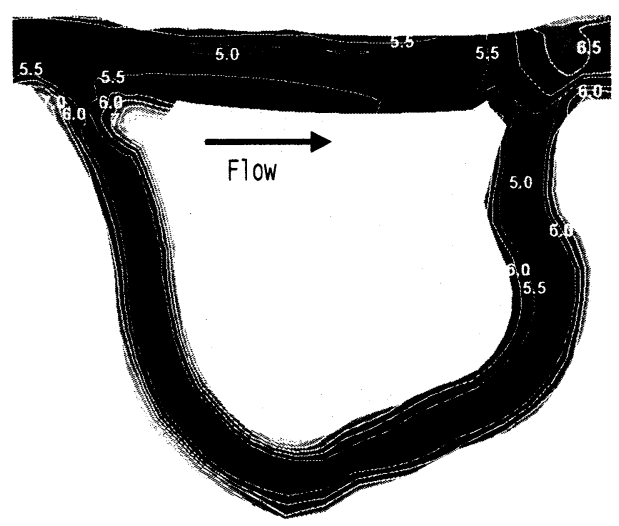

(a) 出水前（02年3月測量）

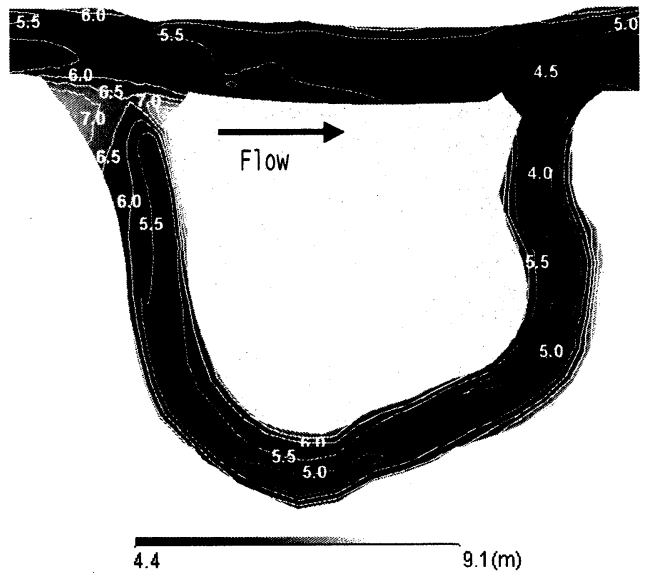

(b) 出水後 $(02$ 年7月測量)

図-3 現地河床高（融雪出水）

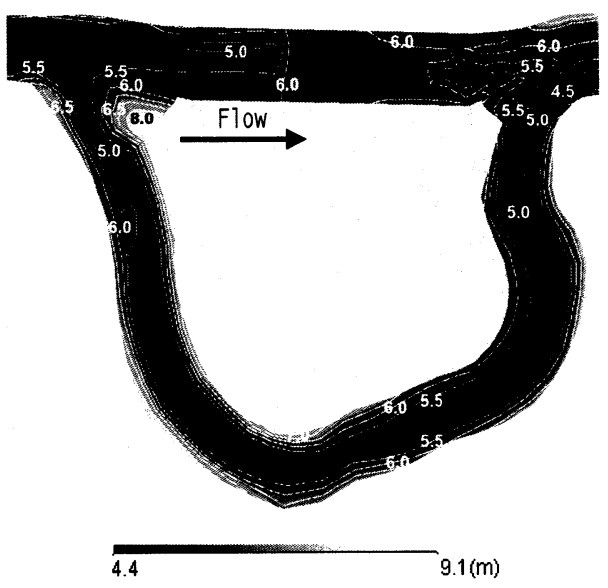

図-4 計算河床高（融雪出水開始1週間後）

量の約6割が流入しているのに対して, 計算でも通水終 了時には全流量の約6割となり, 流量配分は現地を再現 できている.

\section{(3)夏季出水計算結果}

続いて夏季出水について結果を示す. 図-6(a)は夏季出 水前 (9月)，(b)は出水終了後の現地河床高である. 出 水前河床(a)は計算初期河床形状に用いた。 図-7(a)は流量 


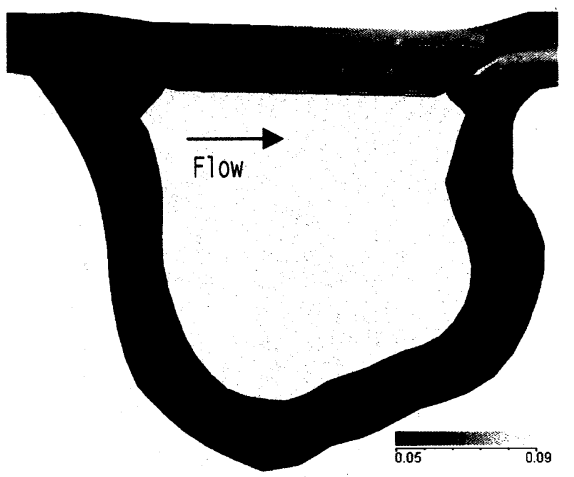

図-5 計算による無次元掃流力の分布(通水終了時) 白線は $\tau^{*}{ }_{c}=0.05$ を示す.

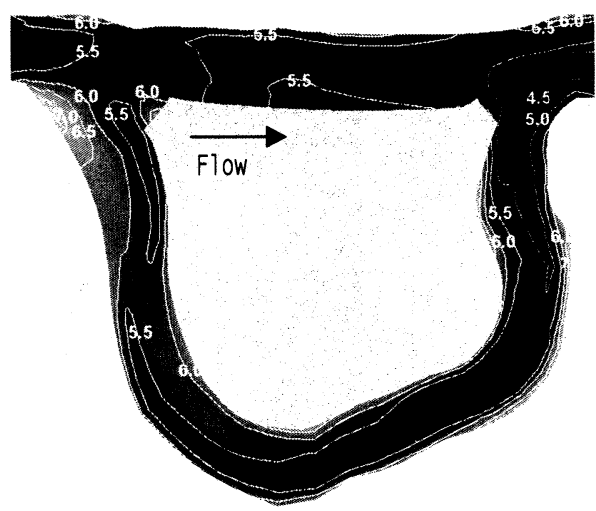

(a)出水前 $(02$ 年9月測量)

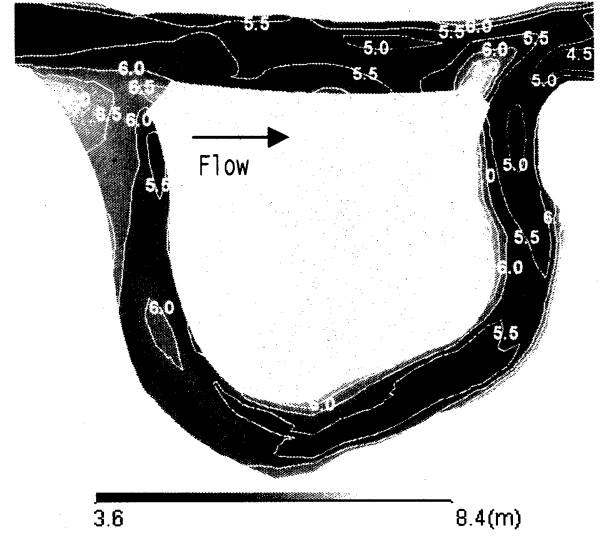

(b)出水後 $(02$ 年 10 月測量 $)$

図-6 現地河床高（夏季出水）

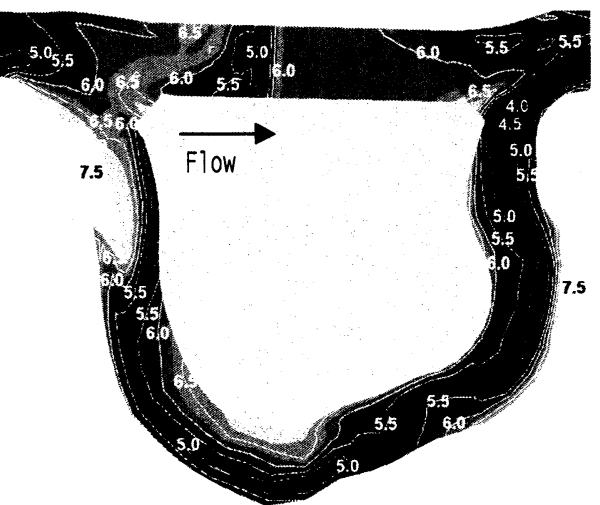

(a) 流量ピーク時 (通水開始15時間後)

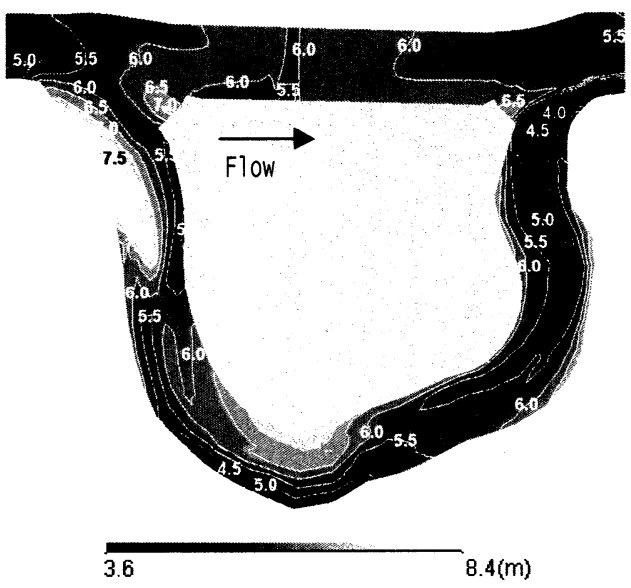

(b) 計算終了時

図-7 計算河床高（夏季出水）

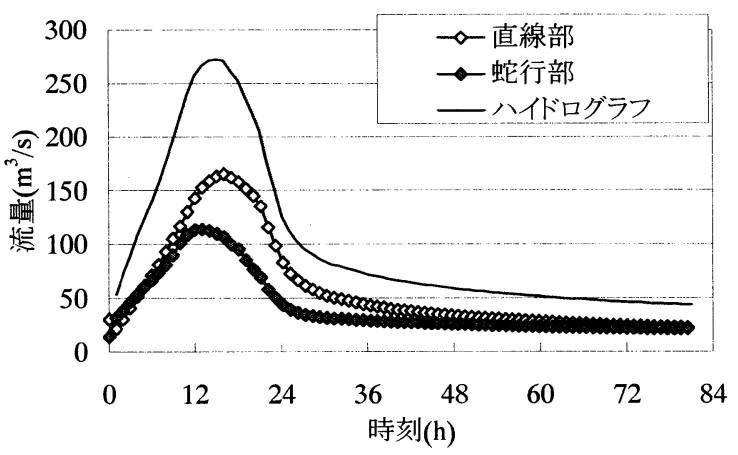

図-8 計算による直線及び蛇行部流量（夏季出水） ピーク時（通水開始15時間経過）の，(b)は出水終了時の 計算河床高である.

蛇行水路入口の現地河床では, 出水前は右岸に堆積, 左岸に洗堀が存在する.同様の傾向は計算でも見られる が, 実測值の方が蛇行入口の河床高が高い. また現地蛇 行水路内では流入口から右岸側で堆積が発達しており, 左岸側には洗堀がみられる. 計算では流量ピーク時に蛇 行部流入口から右岸側に沿って土砂堆積が生じ，左岸側 は河岸近傍で洗堀されている.これらは出水終了時計算 值をみてもほぼ同様の形状である。なお堆積, 洗堀とも に計算結果は現地よりも高低差，規模ともに大きい。

直線河道の計算河床形状は融雪出水時と同様, 堰下流
では堆積傾向にある．堰直上流では流量ピーク時は著し い洗堀が見られるが, 洪水終了時には幾分埋め戻されて いる. 合流部及びその下流を見ると, 現地で出水後に生 じた合流点から直線河道中心部にわたり生じている堆積 は，計算ではその規模が小さく再現されている．まとめ ると河床変動の傾向を再現している箇所もある一方で, 堰近傍では再現性は不十分といえる。

蛇行部への流入量を図-8に示す. 流量ピーク時の蛇行 部分担流量は全流量の1/3，通水終了時は約4割であり， 大規模流量時には直線部が多くの流量を分担するととも に，平水時には蛇行部に相当の流量があるといえる. (4)河岸浸食と河岸近傍流速の関連性 
標津川では蛇行水路の開削後, 流入部付近を中心に河 岸浸食が生じた。そこで浸食の要因について水理量との 関連を調べる. 鈴木らのは標津川の河道災害の要因を検 証する中で，河岸浸食と河岸近傍流速及び偏倚流速（断 面平均流速との差）に相関性があることを示している. そこで計算で再現された河岸近傍流速と河岸浸食量の関 連性について検証する。

図-8に2002年3月測量時を基準とした現地河岸浸食幅 の変遷と融雪出水及び夏季出水ピーク時の両岸近傍流速 及び偏倚流速を示す．偏倚流速 $u^{\prime} は$ 以下の式で定義した.

$$
u^{\prime}=u_{\text {wall }}-u_{m}
$$

ここに $u_{\text {wall }}$ : 河岸近傍流速, $u_{m}$ : 断面平均流速である.

融雪出水が終了した7月の現地河岸浸食は合流点付近 及び $250 \mathrm{~m}$ から上流側の区間で見られ，特に $240 \mathrm{~m} \sim 300 \mathrm{~m}$ の右岸及び350mから上流の左岸で顕著である. 河岸浸 食幅と計算による河岸近傍流速及び偏倚流速の間には明 瞭な相関性は見られない. 特に $350 \mathrm{~m}$ から上流側の分流 点付近までの左岸近傍流速は小さいにも関わらず，現地 では大きく浸食されている．分岐点近傍では流れの3次 元性が強く, 河岸近傍流速によるせん断力以外の要因で 河岸浸食が進行したとも考えられる. 偏倚流速は全体的 に小さく, 河岸浸食との相関は見られない。

夏季出水後の10月の河岸浸食を見ると，7月までに浸 食された区間で浸食がさらに進行しており，特に流れの 分岐点に近い左岸 $350 \mathrm{~m}$ から上流で進行が著しい. 左岸 350mから上流側の河岸近傍流速及び偏倚流速はともに 大きく, 右岸でも河岸近傍流速及び偏倚流速が大きい箇 所と河岸浸食が進行した箇所はある程度重なっている.

なお $100 \mathrm{~m} 〜 240 \mathrm{~m} は$ 相当の流速にも関わらず河岸浸食 幅が小さい。この区間は三日月湖部分であり河岸が植生 に覆われているため, 新規に掘削された上下流区間に比 べて浸食への抵抗が大きいことが考えられる.

以上まとめると，夏季出水規模では計算による河岸近 傍流速及び偏倚流速が大きい箇所と, 河岸浸食が生じる 箇所は重なる傾向が窥え，河岸近傍流速と河岸浸食には ある程度の関連性が推測できる.流量規模が比較的小さ いときや3次元性の流れが強いと考えられる箇所では浸 食と河岸近傍流速及び偏倚流速は関連性が薄い。河岸近 傍計算流速を用いた浸食予測は，夏季出水程度の洪水で 生じる河岸浸食予測に，ある程度有効な手法といえる。

\section{4. 複断面2ウェイ流れの予測}

前章では2ウェイ低水路のみの流れと河床変動を論じ てきたが，出水規模がさらに大きくなれば高水敷も冠水 し，一層複雑な流況や河床変遷が生じる可能性がある. 河道計画策定あるいは河道維持管理を行う上で，高水敷 冠水を考慮した流れと河床形状の予測は重要である. 本 章では2ウェイ低水路を有する複断面水路の流況を計算

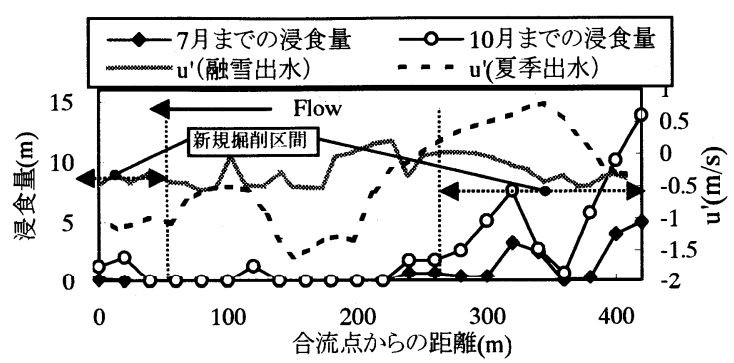

(a) 左岸浸食幅と偏倚流速

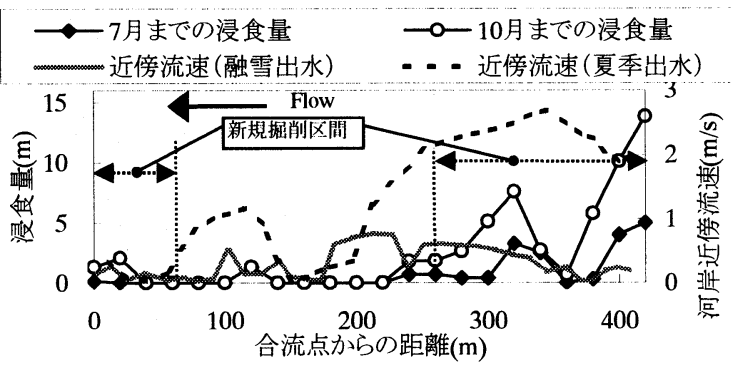

(b) 左岸浸食幅と河岸近傍流速

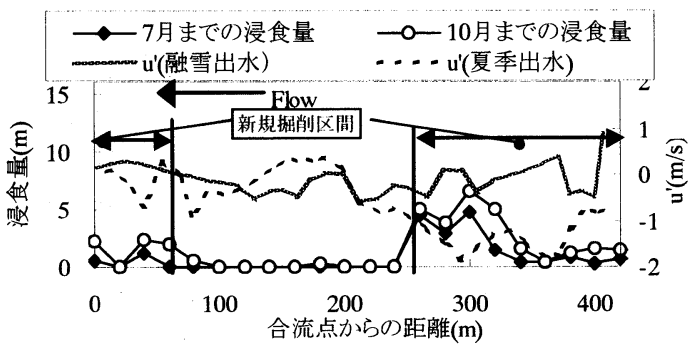

(c) 右岸浸食幅と偏倚流速

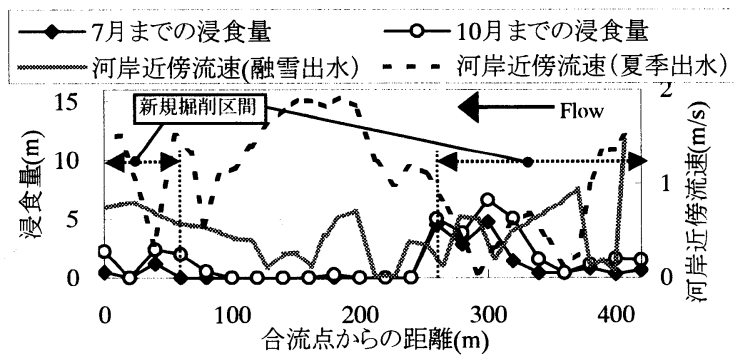

(d) 右岸浸食幅と河岸近傍流速

図-9 現地蛇行部河岸浸食幅と河岸近傍流速及び偏倚流速

した. 直線低水路の有無による流況の違いを検証するた め, 低水路が蛇行水路のみの複断面流れの計算結果と比 較する。なお計算結果を検証すべき実験あるいは現地 データがないので，計算結果をもとにした流況予測を行 うにとどめる.

\section{（1）計算条件}

2ウェイ低水路の計算格子を図-10に示す。標津川に対 して縮尺1/167を想定し，水路勾配は直線部 $1 / 800$, 低水 路幅 $0.3 \mathrm{~m}$, 全水路幅 $2 \mathrm{~m}$, 高水敷上からの深さは $1.7 \mathrm{~cm}$ と した. 蛇行水路の最大蛇行角は $50^{\circ}$, 蛇行長 $4.2 \mathrm{~m}$, 底面 粗度は低水路部で 0.013, 高水敷では 0.02, 河床変動は低 


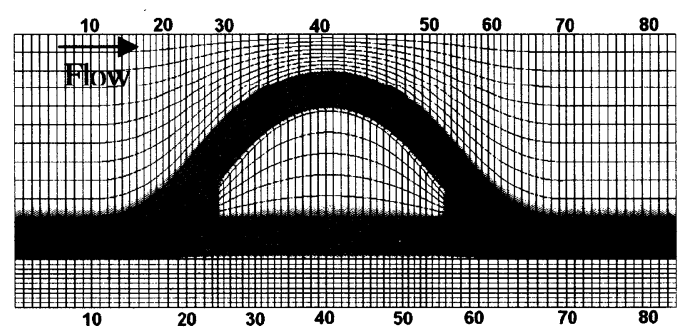

図-10 2ウエイ低水路複断面計算格子

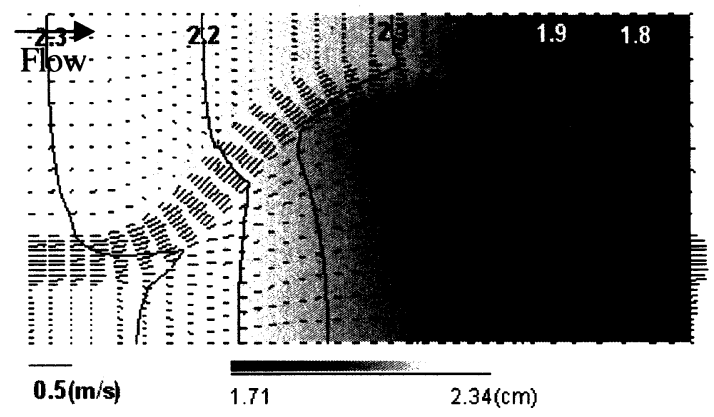

(a) 2ウェイ低水路

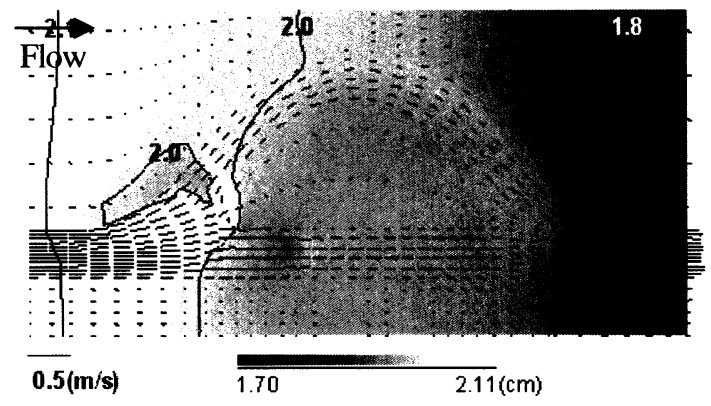

(b) 蛇行低水路のみ

図-11＼cjkstart水位及び流速べクトル（通水開始6時間後）
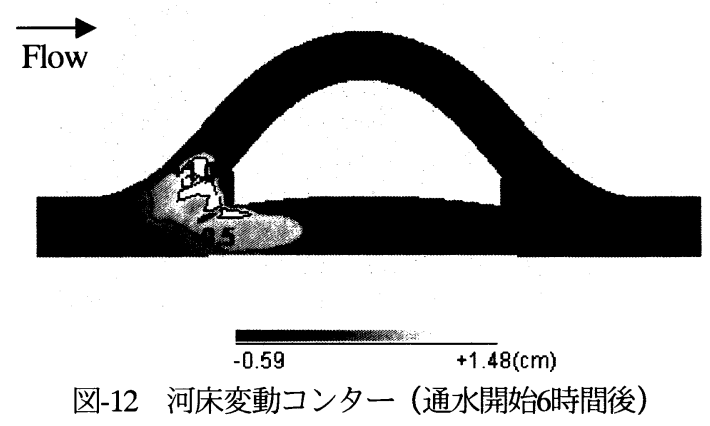

水路のみ生じ，河床材料は単一粒径で $0.2 \mathrm{~mm}$ に設定した。 流量は標津川の計画流量を基に1.67(1/s)とし，上流端で 流量，下流端で等流 $(\mathrm{dh} / \mathrm{dx}=0)$ を設定している．計算の安 定性向上のため，2次流の効果は入れていない.

\section{(2)計算結果}

図-11は通水開始8時間後の2ウェイ低水路及び蛇行低 水路の場合の水位コンタ一及び流速べクトルである. 平 均水深から求めた相対水深 ${ }^{2}$ は2ウェイの場合 0.17 , 蛇行 のみの場合0.19である．流れは低水路に集中しており， 2ウェイ低水路では直線部で最大流速が生じている. 2
ウェイ低水路方式は蛇行低水路のみの場合に比べて高水 敷の水深, 流速ともに蛇行低水路のみの場合に比べて小 さく, 水路全体でみても水位は低くなっている. 直線低 水路の存在が流れに対する抵抗が小さくしたと考えられ， 治水安全性向上が期待できる.

2ウェイ低水路の河床変動を図-12に示す．河床変動は 蛇行部より直線部で著しい。直線部河床高は分岐部から 合流点にかけては上昇傾向，それ以外では低下傾向であ る. 蛇行部は流入部での堆積が顕著である.

\section{5. 結論}

得られた主要な結果を以下にまとめる。

(1)標津川蛇行復元試験施工区間において, 融雪出水及び 夏季出水を対象に計算を行った. 融雪出水時の合流部 下流, 夏季出水時の蛇行流入部の河床変動など, 計算 結果はある程度現地河床変動の傾向を再現することが できた．しかし低水路ならびに分合流点，堰付近では 精度が十分でない箱所も見られた. 今後土砂粒度分布 の考慮等，モデル改善が必要と思われる.

(2)河岸浸食量と河岸近傍流速及び偏倚流速の関係を検証 した結果, 夏季出水では両者の間にはある程度の相関 性が見られ，浸食予測を河岸近傍流速から予測する方 法はある程度有用といえる。

謝辞 : 本研究を行うに当たり，国土交通省北海道開発局 釧路開発建設部より現地資料の提供を受けた。また本研 究は国土交通省北海道開発局の受託業務による補助を受 けて行ったものである。ここに記して謝意を表す。

\section{参考文献}

1)清水康行 : 沖積河川の流れと河床変動の予測手法に関する研 究, 北海道大学学位論文, 1990

2)福岡捷二, 大串弘哉, 加村大輔, 平生昭二 : 複断面蛇行水路 における洪水流の水理、土木学会論文集No579/II-41, pp.8392, 1997

3)福岡捷二, 渡邊明英, 岡田将治 : 静水圧近似3次元解析モデ ルによる複断面蛇行水路河床変動解析，水工学論文集第42巻, pp1015-1020， 1998

4)佐藤耕治, 渡邊康玄, 横山洋, 中津川誠 : 分岐合流部を含む 河道における砂州の影響，水工学論文集第46巻，pp.719-703， 2002.

5)Shimizu,Y. and Itakura,T.: Calculation of flow and bed deformation with a general non-orthogonal coordinate system, Proc. of XXIV IAHR Congress, Madrid, Spain, C-2, pp.41-48, 1991.

6) 鈴木優一, 渡邊康玄, 長谷川和義, 森明巨, 空閑健 : 標津 川蛇行復元における2way河道の通水直後の変化, 水工学論文 集第47巻, pp.703-708, 2003

（2003.9.30受付） 